\title{
Gender Diversity and Financial Stability: Evidence from Malaysian Listed Firms
}

\author{
Mujeeb Saif Mohsen AL-ABSY ${ }^{1}$, Qais ALMAAMARI ${ }^{2}$, Tamer ALKADASH ${ }^{3}$, Ammar HABTOOR ${ }^{4}$
}

Received: September 01, 2020 Revised: October 26, 2020 Accepted: November 05, 2020

\begin{abstract}
This study examines the relationship between gender diversity (women on the board and women on the audit committee) and a firm's financial stability. The ordinary least square analysis was used to determine the relationship. To measure the financial stability of Malaysian suspect firms, i.e., firms with the lowest positive earnings, the Altman (1993) Z-Score measurement was utilized. The results indicate that women on the board are significantly and negatively associated with the firm's financial stability. That is, they are related to low financial stability, which contradicts the agency and resource dependence theories. Regarding women directors on the audit committee, there is no significant relationship with financial stability, meaning that they cannot protect the company against financial distress. These results are robust and do not change when using different measurements of gender diversity, one-year lag of independent variables, and other methods of analysis, namely random effect panel data. This study is the first to alert policymakers, stakeholders, researchers, and society in general to the need to re-evaluate and strengthen the role of women directors in improving firms' financial stability, particularly in emerging economies like Malaysia.
\end{abstract}

Keywords: Gender Diversity, Women Directors, Board of Directors, Audit Committee, Financial Stability, Malaysia

JEL Classification Code: M40, M41, M42, M48

\section{Introduction}

The financial crisis of 2007-09 substantially shook the global community, affecting both the developed and less developed economies and typified by lower economic activity, high unemployment, aggravation of the poverty level, and widening of the gap between rich and poor (Firtescu, 2012). Regulators, investors, and financial communities

${ }^{1}$ FirstAuthor and Corresponding Author. Assistant Professor, Department of Accounting and Finance, College of Administrative and Financial Sciences, Gulf University, Kingdom of Bahrain [Postal Address: Street No. 4324, Sanad, 734, Kingdom of Bahrain]

Email: dr.mujeeb.saif@gulfuniversity.edu.bh

${ }^{2}$ Assistant Professor, Department of Administrative and Human Resource, College of Administrative and Financial Sciences, Gulf University, Kingdom of Bahrain

${ }^{3}$ Assistant Professor, Department of Administrative and Human Resource, College of Administrative and Financial Sciences, Gulf University, Kingdom of Bahrain

${ }^{4}$ Assistant Professor, Faculty of Oil and Minerals, University of Aden, Aden, Yemen

(C) Copyright: The Author(s)

This is an Open Access article distributed under the terms of the Creative Commons Attribution Non-Commercial License (https://creativecommons.org/licenses/by-nc/4.0/) which permits unrestricted non-commercial use, distribution, and reproduction in any medium, provided the original work is properly cited. recognize the importance of a healthy, secure, and balanced economic and financial environment (Rubio \& Yao, 2020), with constant, effective monitoring and scrutiny of financial stability (Chirila \& Chirila, 2015). The root of unstable financial conditions, as suggested by the European Central Bank (ECB) (2010) annual report, is a mismatch between the balance sheet and high leverage of debt, and the rapid growth of financial institutions. These are all components of corporate governance (CG) ( Lupu, 2015).

The global financial crisis has therefore resulted in the re-examination of CG practices (Anginer, Demirguc-Kunt, Huizinga, \& Ma, 2018; Lupu, 2015) in supporting financial stability (Lupu, 2015). Most policy decision-makers have questioned the extent to which managerial dominance and the inability of boards to supervise executives might have led to unwarranted risk-taking and financial instability (Anginer et al., 2018). It is argued that weak firm performance and high risk contribute significantly to financial instability; they are the negative consequences of board failure in performing the assigned tasks efficiently (Abdelbadie \& Salama, 2019).

In the Malaysian context, the economic crisis in the middle of 1997 demonstrated the effects of weak CG (Abdul-Rahman \& Ali, 2006; Ow-Yong \& Kooi-Guan, 2000). Since then, the spotlight has moved on to $C G$ 
(Shahwan, 2015), with measures taken by the government to boost the effectiveness of CG. Commencing in 1999 with the formation of a robust Finance Committee on Corporate Governance (FMCG), the committee conducted a review of $\mathrm{CG}$ and began the reformation of the Malaysian Code of Corporate Governance (MCCG), leading to the modification of the CG Code in 2000, 2007, 2012 and more recently in 2017.

The role of CG, like the board of directors, has been studied extensively (Abdelbadie \& Salama, 2019). Earlier researchers have examined in-depth the effect of CG in respect of financial reporting quality, for instance, earnings management (EM), timely financial reporting, and firm performance. The impact of CG on a firm's financial distress has been examined, for example, CEO duality, the independence of the board, including ownership structure (Abdullah, 2006); CEO duality, the existence of an audit committee (AC), the directorship and external ownership as well as the board structure (Miglani, Ahmed, \& Henry, 2015); CEO duality, the board size, board structure, an independent board, and AC structure (Elloumi \& Gueyie, 2001); board chairman's characteristics (Al-Absy, 2020); shares held by the controlling shareholders pledged for bank loans, controlling shareholding directors, and the deviation in control away from the cash flow rights (Lee \& Yeh, 2004). However, to the best of our knowledge, no study has been made of the influence of women directors on financial stability.

The presence of women on the board of directors is one of the most important requirements of CG. The number of women directors is being increased voluntarily or through legislation in many countries, in recognition of the value of their participation (Abdullah, Ku Ismail, \& Nachum, 2016; Srinidhi, Gul, \& Tsui, 2011). Norway, Spain, Sweden, Israel, and France have legislated for $40 \%, 40 \%$, $25 \%, 50 \%$, and $50 \%$ women representation on the board, respectively (Burke \& Vinnicombe, 2008; Gavious, Segev, $\&$ Yosef, 2012; Staubo, 2010). Likewise, the Malaysian government in 2004 formulated a policy which stipulates that by $2016,30 \%$ of high-level decision-making officers in the public sector should be women; the policy was extended to the private sector in 2011 (Abdullah, 2014; Abdullah \& Ku Ismail, 2016; Ku Ismail \& Abdullah, 2013). The current policy (2020) is that all firms have to include at least $30 \%$ of women on their boards. To ensure the listed firms' compliance with its regulations, the MCCG (version 2012) required boards to develop and report on their position on gender equality and how this aim should be accomplished.

This study examines the association between women on the board and AC and the firm's financial stability. It contributes to the literature in various ways. First, it extends knowledge by providing evidence of the impact of women directors on firms' financial stability, a topic that has not been examined yet. Second, the results may help regulators, policymakers, and shareholders to determine whether to increase the percentage of women representatives on the board and AC. The reason for selecting Malaysia for this research is that its business environment has certain attributes that can influence the practice of CG. Two elements distinguish the ownership of Malaysian companies: concentrated shareholdings held by a family or individual, and the large proportion of government equity (Abdullah, 2006). These two features might influence the nomination of women directors to either the board or AC. The Malaysian perspective is also significant as a result of numerous revisions by the regulatory authorities to the MCCG (2007, 2012, and 2017), in an attempt to improve the code. This implies that the earlier versions can be regarded as incomplete or difficult to apply.

\section{Literature Review}

Women directors on the board are increasingly seen as important (Srinidhi et al., 2011). They can strengthen their monitoring role (Adams \& Ferreira, 2009) to enhance boardroom capabilities (Mathisen, Ogaard, \& Marnburg, 2013) and are more likely to be independent (Bohren \& Staubo, 2016; Staubo, 2010). Accordingly, gender diversity, as one of the board mechanisms, helps to solve the agency problems between owners and executives (Fama \& Jensen, 1983).

From the perspective of resource dependence theory, the board structure is a strategic tool that helps to link external resources and the firm, thereby creating value. The board composition is thus influenced by environmental pressures and demands (Boyd, 1990). For example, pressure from society to appoint women directors to the board has increased (Luckerath-Rovers, 2009), as their presence is significantly related to higher firm performance (Abdullah et al., 2016; Adams \& Ferreira, 2009), firm value (Carter, Simkins, \& Simpson, 2003), and earnings quality (Srinidhi et al., 2011).

Women directors are equal and at times superior to their male counterparts in many aspects: education, knowledge, skills, ethics, reputation, and the ability to recognize the misuse of earnings (Lakhal et al, 2015; Singh, Terjesen, \& Vinnicombe, 2008). Adams and Ferreira (2009) state that boards with a higher percentage of women directors guarantee improved decision making and strict supervision of CEOs to be aligned with shareholders'interests.

Women directors are more independent and can strengthen the monitoring role of the board more readily than male directors (Bohren \& Staubo, 2016; Carter et al., 2003; Staubo, 2010). They ask more questions (Carter et al., 2003) and participate more during meetings (Adams \& Ferreira, 2009; Carter et al., 2003), expressing different points of 
Mujeeb Saif Mohsen AL-ABSY, Qais ALMAAMARI, Tamer ALKADASH, Ammar HABTOOR /

Journal of Asian Finance, Economics and Business Vol 7 No 12 (2020) 181-193

view (Mathisen et al., 2013). Chen, Eshleman, and Soileau (2016) conducted a study with 4267 firm-year observations for 2004 to 2013 and showed that women board directors are negatively related to internal control issues.

\section{Hypothesis Development}

\subsection{Women on the Board}

Concerning performance, women directors are significantly and positively associated with firm value (Carter et al., 2003) and with firm performance (Adams \& Ferreira, 2009; Campbell \& Mínguez-Vera, 2008). However, Wang and Clift (2009) found no relationship between women directors and firm performance. Concerning Malaysia, Abdullah et al. (2016) found that women directors have a significant relationship with lower market performance (Tobin's Q) and higher accounting performance (ROA), while Yusoff, Fauziah, and Ramin (2013) found no relationship. In terms of earnings quality, women directors are significantly related to higher-quality earnings (Srinidhi et al., 2011). However, Upadhyay and Zeng (2014) found that a higher proportion of women directors had a significant relationship with lower corporate opacity (transparency).

Regarding the association between women on the board and earnings management (EM) (a measurement of financial reporting quality), a review of the literature on developed countries has found that women directors are significantly associated with lower EM (Gavious et al., 2012; Gul, Srinidhi, \& Tsui, 2007; Gull et al., 2018; Kyaw, Olugbode, \& Petracci, 2015; Lakhal et al., 2015). This means that women on the AC significantly improve the quality of financial reporting, supporting both agency and resource dependence theories, although Arun, Almahrog, and Aribi (2015) found that women directors are significantly associated with higher levels of EM. In developing countries, however, Moradi et al. (2012) found no relationship between women directors and EM. These results, which are incompatible with agency and resource dependence theories, suggest that because women's representation on boards is small, their actual effect on EM may also be small (Arun et al., 2015; Moradi et al., 2012).

In the context of Malaysia, some previous studies, such as Buniamin et al. (2012), have found that women on the board are significantly associated with higher EM. However, $\mathrm{Ku}$ Ismail and Abdullah (2013) have found that they are significantly related to lower EM, while (Abdullah \& $\mathrm{Ku}$ Ismail, 2012, 2016) found no relationship. The positive result of Buniamin et al. (2012) cannot be generalized as it has some limitations: (i) it selected only the year 2008 and (ii) it included only leverage and cash flow as control variables while ignoring other firm-specific and governance variables (Abdullah \& Ku Ismail, 2016). Similarly, the negative result of Ku Ismail and Abdullah (2013) may not be generalized as it also considered only the year 2008 and one measurement for women on the board.

In general, the low number of women directors does not help in mitigating EM or enhancing the quality of financial reporting as their voice is weaker (Abdullah \& $\mathrm{Ku}$ Ismail, 2012, 2016). Empirically, Abdullah and $\mathrm{Ku}$ Ismail (2016) found that the proportion of firms with women directors on their boards was low (43\%) and the majority of these firms $(69 \%)$ had only one women director. Although their study extended the firm sample (2412 firm-year observations) and the period of study (2008 to 2011) and used several measurements for women on the board, their findings show that EM was not significantly mitigated. Nevertheless, with the support of agency and resource dependence theories, the following hypothesis is proposed:

H1: There is a positive relationship between women on the board and a firm's financial stability.

\subsection{Women on the Audit Committee (AC)}

Having women directors on the AC could improve the committee's effectiveness. Women directors are more independent (Bohren \& Staubo, 2016; Staubo, 2010); more likely to support shareholders' interests (Adams \& Ferreira, 2009); and more ethical and more likely to detect earnings manipulation (Lakhal et al., 2015). Hence, they may strengthen the monitoring role of the $\mathrm{AC}$ in improving the quality of earnings and financial reporting, aligning with the theories of agency and resource dependence. Most previous studies such as Gavious et al. (2012), Gul et al. (2007), Thiruvadi and Huang (2011) Zalata, Tauringana, and Tingbani (2018) have concluded that, in developed countries, women on the AC positively influence the quality of financial reporting, measured by EM. Similarly, studies by Ku Ismail and Abdullah (2013), Salleh, Hashim, and Mohamad (2012), and Zalata, Tauringana, and Tingbani (2018) have concluded that, in Malaysia, women on the AC positively influence the quality of financial reporting, measured by EM. This means that women on the AC may significantly improve the firm's financial stability.

However, other studies have found no relationship between women on the AC and the quality of financial reporting, measured by EM, in developed countries (Sun, Liu, \& Lan, 2011) and in Malaysia (Abdullah \& Ku Ismail, 2012, 2016; Salleh \& Haat, 2013). This means that women on the $\mathrm{AC}$, in some circumstances, are unable to improve the quality of financial reporting. Nevertheless, based on the theories of agency and resource dependence and with support from previous studies, the following hypothesis is presented:

H2: There is a positive relationship between women on the audit committee and a firm's financial stability. 


\section{Research Methodology}

\subsection{Sample Selection}

This research encompasses three successive years, 2013 to 2015. Sample selection was based on earnings figures measured by the ratio of return on asset (ROA), obtained through DataStream, as ROA provides investors with a clear picture of how efficient a firm's managers are at making earnings relative to the firm's assets. In Bursa, Malaysia, firms should have an uninterrupted profit of three to five full financial years to get listed in the main market. As in earlier studies which selected suspect firms, i.e., ROA from zero to 0.01 (Ugrin, Mason, \& Emley, 2017) and from zero to 0.005 (Roychowdhury, 2006; Yuliana, Anshori, \& Alim, 2015), firms with one or more years of negative ROA were omitted. Then, the average ROA for each firm was calculated (ROA for 2013, 2014, and 2015 , divided by 3 ) and placed in ascending order to identify the 300 firms with lower than average ROA (AlAbsy, Ismail, \& Chandren, 2021; Al-Absy et al., 2020; Al-Absy, Ku Ismail, \& Chandren, 2018, 2019a, 2019b, 2019c, 2019d). 18 firms were eliminated from the sample because of incomplete data, leading to a final sampling size of 282 firms, or 846 firm-observations over the three years.

\subsection{Regression Models}

The regression model was used to determine the influence of women on the board and the AC on the firm's financial stability. Numerous control variables were integrated into the model, including size and frequency of meetings of the board and $\mathrm{AC}$, ownership concentration, type of audit firm, sales growth, leverage, return on assets (ROA), and manufacturing industry, to control the relationships. The following equation was calculated; details of the measurement of the variables are presented in Table 1.

$$
\begin{aligned}
\text { Z-Score } & =\beta_{0}+\beta_{1} \text { WOB }+\beta_{2} \text { WOAC }+\beta_{3} \text { BSIZE } \\
& +\beta_{4} \text { BMEET }+\beta_{5} \text { ACSIZE }+\beta_{6} \text { ACMEET } \\
& +\beta_{7} \text { Big } 4+\beta_{8} \text { Conc } 5+\beta_{9} \mathrm{SG}+\beta_{10} \text { LEV } \\
& +\beta_{11} \text { ROA }+\beta_{12} \text { INDUS }+\varepsilon
\end{aligned}
$$

To offer robust results, the research re-estimated the core model, first by including a dummy variable for the three years (Sakawa \& Watanabel, 2018) to control changes or discrepancies across the year. Second, dummy variables were integrated for the company sector (consumer, construction, industrial products, properties, plantation, technology, trade, and services), in place of INDUS in the main model, in addition to the year dummy variable.

Table 1: Summary of Variable Measurements

\begin{tabular}{|l|c|l|}
\hline Variables & Acronym & \multicolumn{1}{|c|}{ Measurement and Sources } \\
\hline Financial stability & Z-Score & $\begin{array}{l}\text { "1.2 * (working capital / total assets) }+1.4^{*} \text { (retained earnings / total assets) } \\
+3.3^{*} \text { (earnings before taxes and interest / total assets) + } 0.6 \text { * (market value } \\
\text { of equity / total liabilities) }+1.0 \text { * (net sales / total assets)" (Wan-Hussin \& } \\
\text { Bamahros, 2013). }\end{array}$ \\
\hline Women on the board & WOB & "1" if the board has at least one women, and "0" otherwise \\
\hline Women in the AC & WOAC & "1" if the AC has at least one women, and "0" otherwise \\
\hline Board size & BSIZE & Number of directors. \\
\hline Board meeting & BMEET & Number of meetings per year. \\
\hline AC size & ACSIZE & Number of directors. \\
\hline AC meeting & ACMEET & Number of meetings per year. \\
\hline Ownership concentration & Conc5 & Percentage of outstanding shares owned by the largest five shareholders. \\
\hline Big-4 audit firms & Big-4 & "1" if firms were audited by Big 4 firms, and "0", otherwise. \\
\hline Sales growth & SG & (Sales of this year - sales of the previous year) / sales of the previous year \\
\hline Return on assets & ROA & Net income/total assets. \\
\hline Leverage & LEV & Total debt to total assets. \\
\hline Industry & INDUS & "1" for observation in the manufacturing industry, and "0", otherwise. \\
\hline
\end{tabular}




\subsection{Descriptive Statistics}

Table 2 shows that the mean value of financial stability is 2.761, suggesting that the firms selected generally fall into the grey area (Z-Score mean 1.81 to 2.99 ). In other words, the firms are not in serious financial distress because the value of Z-Score is not below 1.81; nevertheless, they are not financially stable as the average is less than 2.99 (Altman, 1968). Table 2 also shows that $451(53.31 \%)$ firm-year observations indicate the appointment of at least one woman director on the board (WOB). This result is higher than that of Abdullah and $\mathrm{Ku}$ Ismail (2016), who reported that the proportion of firms with women directors on their boards was low (43\%) for the period 2008 to 2011. This indicates that more than one woman on the board, showing a slight increase over time. 217 (25.65\%) firmyear observations indicate the presence of at least one woman director on the AC (WOAC), again higher than that of Abdullah and $\mathrm{Ku}$ Ismail (2012) where 109 (17\%) firm-year observations were reported for the year 2008. However, it is lower than that of Abdullah and $\mathrm{Ku}$ Ismail (2016), wherein 856 (35\%) firmyear observations were reported for the period 2008 to 2011.

Concerning the control variables, the mean value of board size (BSIZE) is 7.413 directors while the frequency of meetings (BMEET) is 5.611 times a year. The mean value of $\mathrm{AC}$ size (ACSIZE) is 3.236 and the frequency of meetings (ACMEET) 5.054 times a year. The mean percentage of shares owned by the largest five shareholders is $54.60 \%$, and Big-4 companies are the auditors in 444 (52.48\%) firmyear observations (Big-4). Regarding the company-specific characteristics, the average value of return on assets (ROA), leverage (LEV), and sales growth (SG) is $4.41 \%, 20.87 \%$, and $7.80 \%$, respectively. Lastly, the result shows that 360 $(42.55 \%)$ firm-year observations are for manufacturing firms (INDUS).

\subsection{Diagnostic Tests}

To address the outlier problem, the research winsorized the extreme values of some observations: Z-score, BMEET, and SG by applying $2 \%$ and ACMEET by applying $1 \%$ for the top and bottom observations. Table 2 indicates that the skewness and kurtosis for all variables are within the acceptance level, which means that all variables are normally distributed. In terms of multicollinearity, Table 3 shows that there is no evidence of severe problems as the value of correlations does not exceed the threshold of \pm 0.80 .

Table 2: Descriptive Statistics for the Continuous Variables

\begin{tabular}{|c|c|c|c|c|c|}
\hline \multicolumn{6}{|c|}{ A. Continuous Variables } \\
\hline Variable & Mean & Min. & Max. & Skewness & Kurtosis \\
\hline Z-Score & 2.761 & 0.405 & 10.060 & 1.886 & 7.091 \\
\hline BSIZE & 7.413 & 4.000 & 17.000 & 0.991 & 4.811 \\
\hline BMEET & 5.611 & 4.000 & 14.000 & 2.335 & 9.010 \\
\hline ACSIZE & 3.236 & 3.000 & 6.000 & 2.233 & 8.597 \\
\hline ACMEET & 5.054 & 3.000 & 10.000 & 1.823 & 7.706 \\
\hline Conc5 & 0.546 & 0.141 & 0.948 & -0.092 & 2.315 \\
\hline SG & 0.078 & -0.509 & 1.263 & 1.652 & 7.675 \\
\hline LEV & 20.873 & 0.000 & 68.560 & 0.414 & 2.452 \\
\hline ROA & 4.411 & 0.010 & 15.160 & 0.654 & 3.562 \\
\hline \multicolumn{6}{|c|}{ Continues Table 2, Descriptive Statistics for Dummy Variables } \\
\hline \multirow{2}{*}{ B. Dummy Variables } & \multicolumn{2}{|c|}{ Yes (1) } & \multicolumn{2}{|c|}{ No (0) } & \\
\hline & Freq. & Percent & Freq. & Percent & \\
\hline WOB & 451 & 53.31 & 395 & 46.69 & \\
\hline WOAC & 217 & 25.65 & 629 & 74.35 & \\
\hline Big4 & 444 & 52.48 & 402 & 47.52 & \\
\hline INDUS & 360 & 42.55 & 486 & 57.45 & \\
\hline
\end{tabular}


Table 3: Pearson Correlation

\begin{tabular}{|c|c|c|c|c|c|c|c|c|c|c|c|c|c|}
\hline Variables & Z-Score & WOB & WOAC & BSIZE & BMEET & ACSIZE & ACMEET & SG & LEV & ROA & Big4 & Conc5 & INDUS \\
\hline Z-Score & 1 & & & & & & & & & & & & \\
\hline WOB & 0.009 & 1 & & & & & & & & & & & \\
\hline WOAC & $0.056^{*}$ & 0.550 & 1 & & & & & & & & & & \\
\hline BSIZE & 0.015 & $0.143^{* * *}$ & $0.073^{* *}$ & 1 & & & & & & & & & \\
\hline BMEET & $-0.111^{* * *}$ & $0.071^{* *}$ & $0.098^{* * *}$ & $0.212^{* \star *}$ & 1 & & & & & & & & \\
\hline ACSIZE & 0.002 & -0.013 & $0.064^{*}$ & $0.299^{* * *}$ & $0.301^{* * *}$ & 1 & & & & & & & \\
\hline ACMEET & $-0.154^{\star \star \star}$ & $0.083^{* *}$ & $0.088^{* *}$ & $0.148^{\star * *}$ & $0.587^{* * *}$ & $0.152^{* * *}$ & 1 & & & & & & \\
\hline SG & -0.022 & 0.023 & 0.019 & 0.021 & -0.027 & -0.049 & 0.001 & 1 & & & & & \\
\hline LEV & $-0.581^{* * *}$ & $-0.114^{* * *}$ & $-0.137^{* * *}$ & $0.140^{* * *}$ & $0.084^{* *}$ & -0.010 & $0.127^{* * *}$ & 0.033 & 1 & & & & \\
\hline ROA & $0.239^{* * *}$ & 0.056 & -0.021 & $0.081^{* *}$ & -0.003 & -0.014 & -0.051 & $0.176^{* * *}$ & $-0.097^{* * *}$ & 1 & & & \\
\hline Big4 & -0.055 & $0.096^{* * *}$ & $0.147^{* * *}$ & $0.121^{* * *}$ & $0.171^{* * *}$ & $0.192^{* * *}$ & $0.117^{* * *}$ & -0.055 & $0.131^{* * *}$ & 0.015 & 1 & & \\
\hline Conc5 & $0.164^{\star * \star}$ & 0.042 & $0.107^{* \star *}$ & 0.042 & $0.139^{\star * *}$ & $0.071^{* *}$ & $0.074^{* *}$ & 0.043 & $-0.086^{* *}$ & -0.002 & $0.088^{* *}$ & 1 & \\
\hline INDUS & $0.146^{* * *}$ & 0.029 & $-0.062^{*}$ & $-0.0928^{* * *}$ & $-0.248^{* * *}$ & $-0.160^{\star \star \star}$ & $-0.145^{\star \star *}$ & -0.009 & -0.024 & 0.026 & $-0.129^{* * *}$ & -0.003 & 1 \\
\hline
\end{tabular}

The study also used the variance inflation factor (VIF) to test for the collinearity problem. The results show that none of the tolerance values is less than 0.25 , and none of the VIF values is higher than 4 , which indicates that there is no collinearity problem. The Breusch-Pagan/Cook-Weisberg tests provide evidence of the existence of heteroscedasticity, although Wooldridge's test shows no evidence of an autocorrelation problem. Thus, the study runs the regression with the robust functionality to control for the heteroscedasticity problem.

\section{Results and Discussion}

Ordinary Least Square (OLS) regression was used since the data duration is only three years. All models are significantly fit and have a high $\mathrm{R}^{2}$ value. This indicates that the variables describe the problem of the financial stability of the firm in depth. Table 4 reveals that the presence of at least one woman director on the board is significantly and negatively associated with the firm's financial stability, meaning that the appointment of at least one woman is related to low firm financial stability, contradicting the agency and dependent resource theories. This outcome indicates that women board members still face obstacles in protecting the stakeholders' interests. This result is consistent with Buniamin et al. (2012) in the context of Malaysia, such as, who found that women on the board are related to high EM, resulting in low financial reporting quality.

Furthermore, the presence of women directors on the AC was not significantly associated with the firm's financial stability. This result agrees with several prior studies in Malaysia (Abdullah \& Ku Ismail, 2012, 2016; Salleh \& Haat,
2013) which found that women directors on the AC do not significantly mitigate EM and face difficulties in improving the quality of reporting. Indeed, the small number of women directors on the $\mathrm{AC}$ as well as the need to improve their effectiveness are the major reasons for their low monitoring role (Salleh \& Haat, 2013). This result is inconsistent with agency and resource dependence theories, as well as, the findings of several studies in developed countries such as Gavious et al. (2012), Gul et al. (2007), Thiruvadi and Huang (2011), and Zalata et al. (2018), and a few studies in Malaysia such as Ku Ismail and Abdullah (2013) and Salleh et al. (2012), which found a negative relationship between women directors on the AC and EM; that is, women on the $\mathrm{AC}$ significantly enhance the quality of financial reporting.

Concerning control variables, the result shows that a larger board size results in greater financial stability, which agrees with Geraldes-Alves (2011), who observed that boards with more directors are related to improved or goodquality reporting measured by the EM proxy. The results also show that financial stability is greater in firms with more concentrated ownership. Geraldes-Alves (2011) and Alves (2012) discovered a similar result with the reporting quality, measured by EM. The findings suggest that firms with a large ROA ratio are more likely to be financially stable, as are firms in the manufacturing sector. However, financial stability may be lower in firms with frequent $\mathrm{AC}$ meetings. The result agrees with Salleh et al. (2012), who discovered a lower financial reporting quality, proxied by $\mathrm{EM}$, for firms with more AC meetings. Furthermore, the findings showed that a greater ratio of leverage results in low financial stability. 
Mujeeb Saif Mohsen AL-ABSY, Qais ALMAAMARI, Tamer ALKADASH, Ammar HABTOOR /

Journal of Asian Finance, Economics and Business Vol 7 No 12 (2020) 181-193

Table 4: Regression Using the Ordinary Least Square (OLS)

\begin{tabular}{|c|c|c|c|}
\hline \multirow{2}{*}{ Variables } & \multicolumn{3}{|c|}{ At Least One Woman Director } \\
\hline & Model 1 & Model 2 & Model 3 \\
\hline \multirow[t]{2}{*}{ WOB } & $-0.397^{\star \star *}$ & $-0.398^{\star * \star}$ & $-0.326^{* * *}$ \\
\hline & $(0.115)$ & $(0.116)$ & $(0.114)$ \\
\hline \multirow[t]{2}{*}{ WOAC } & 0.144 & 0.145 & 0.106 \\
\hline & $(0.136)$ & $(0.136)$ & (0.137) \\
\hline \multirow[t]{2}{*}{ BSIZE } & $0.116^{* * *}$ & $0.116^{* * *}$ & $0.126^{\star * *}$ \\
\hline & $(0.0316)$ & $(0.0316)$ & $(0.0284)$ \\
\hline \multirow[t]{2}{*}{ BMEET } & -0.0375 & -0.0377 & -0.0251 \\
\hline & $(0.0305)$ & $(0.0306)$ & $(0.0299)$ \\
\hline \multirow[t]{2}{*}{ ACSIZE } & -0.0609 & -0.0612 & $-0.227^{* *}$ \\
\hline & $(0.133)$ & $(0.133)$ & $(0.114)$ \\
\hline \multirow[t]{2}{*}{ ACMEET } & $-0.0870^{*}$ & $-0.0865^{*}$ & $-0.100^{* *}$ \\
\hline & $(0.0472)$ & $(0.0472)$ & $(0.0443)$ \\
\hline \multirow[t]{2}{*}{ SG } & -0.257 & -0.264 & -0.277 \\
\hline & $(0.204)$ & $(0.202)$ & $(0.194)$ \\
\hline \multirow[t]{2}{*}{ LEV } & $-0.0710^{* * *}$ & $-0.0709^{* * *}$ & $-0.0642^{* * *}$ \\
\hline & $(0.00427)$ & $(0.00427)$ & (0.00382) \\
\hline \multirow[t]{2}{*}{ ROA } & $0.138^{* * *}$ & $0.138^{* * *}$ & $0.156^{* * *}$ \\
\hline & $(0.0208)$ & $(0.0206)$ & $(0.0192)$ \\
\hline \multirow[t]{2}{*}{ Big4 } & 0.104 & 0.104 & -0.0218 \\
\hline & (0.108) & (0.108) & $(0.0963)$ \\
\hline \multirow[t]{2}{*}{ Conc5 } & $1.464^{* * *}$ & $1.465^{\star \star *}$ & $1.395^{\star \star *}$ \\
\hline & $(0.292)$ & $(0.292)$ & $(0.283)$ \\
\hline \multirow[t]{2}{*}{ INDUS } & $0.492^{* * *}$ & $0.491^{* * *}$ & - \\
\hline & $(0.0985)$ & $(0.0986)$ & - \\
\hline Year dummy & & included & included \\
\hline Sector dummy & & & included \\
\hline \multirow[t]{2}{*}{ Constant } & $2.751^{* * *}$ & $2.725^{* * *}$ & $3.061^{* * *}$ \\
\hline & $(0.461)$ & $(0.466)$ & $(0.439)$ \\
\hline F-value & 37.23 & 37.23 & 31.58 \\
\hline Sig. & 0.0000 & 0.0000 & 0.0000 \\
\hline R-squared & 0.4249 & 0.4249 & 0.4843 \\
\hline Observ. & 846 & 846 & 846 \\
\hline \multicolumn{4}{|c|}{$\begin{array}{l}\text { *, }{ }^{* *},{ }^{* * *} \text { are significant at level } 0.10,0.05 \text { and } 0.01 \text {, respectively. } \\
\text { The robust standard errors are in the parentheses. Model } 1 \text { is the } \\
\text { main Model. Model } 2 \text { is re-estimated the main model by including } \\
\text { a dummy variable for the years. Model } 3 \text { is re-estimated the main } \\
\text { model by including the company sector (construction, properties, } \\
\text { industrial products, plantation, consumer, technology, trade, and } \\
\text { services), instead of the manufacturing industry (INDUS). Variables } \\
\text { were described in Table } 1\end{array}$} \\
\hline
\end{tabular}

Finally, Table 4 shows that financial stability is not associated with the frequency of meetings of the board thus confirming the findings of Habbash (2011); with AC size, thus confirming the findings of Abdullah \& $\mathrm{Ku}$ Ismail (2016) and Salleh et al. (2012); with Big-4 audit firms, thus confirming the findings of Abdullah \& Ku Ismail (2016); and with sales growth, thus confirming the findings of Mohammad, Wasiuzzaman, \& Salleh (2016).

\section{Robustness Tests}

\subsection{Regression Using Different Measurement of Gender Diversity}

A further test was conducted to re-estimate the regression by using a different proxy of gender diversity. The total number and the percentage of women on the board were used instead of the previous proxy, dummy variable of " 1 " if the board has a female director, and " 0 " otherwise. Likewise, the total number and the percentage of women on the $\mathrm{AC}$ was used instead of the previous proxy, dummy variable of " 1 " if the $\mathrm{AC}$ has a woman director, and "0" otherwise. Table 5 shows the same results as in Table 4.

\subsection{Regression using the Lag of the Independent Variables}

Although a wide range of variables related to corporate and firm-specific characteristics was employed to control the endogeneity issue (Prencipe \& Bar-Yosef, 2011), it was still necessary to test the endogeneity problem (Larcker \& Rusticus, 2010). Hence, this research re-estimated models of regression with lagged independent variables, following previous studies (Al-Jaifi, Al-Rassas, \& AL-Qadasi, 2017) to control the potential reverse causality. Table 6 shows the same results as in Table 4. Although the result does not appear significant in Model 3 column 1, it was very close to being significant where the P-value is 0.105 . All the other results are the same as in Table 6. Consequently, there is no issue of endogeneity in the findings.

\subsection{Regression Using Different Method of Analysis (Random Effect Panel Data)}

For the number of years used in this study, that is three, panel regression is suggested. Hence, the random effect panel regression with the option 'robust' for the main Model (using dummy proxy " 1 " if there is a woman director, and " 0 " otherwise) was used to check how stable the findings are. The results of gender diversity presented in Table 7 are the same as in Table 4 (using OLS regression). Although the result is not significant in Model 3, it is very close to being significant where the P-value is 0.107 . Regarding control variables, the results are largely similar to the previous ones, meaning that the findings are robust. 
Table 5: Regression Using the Different Measurement of Gender Diversity

\begin{tabular}{|c|c|c|c|c|c|c|}
\hline \multirow{2}{*}{ Variables } & \multicolumn{3}{|c|}{ Number of Women Directors } & \multicolumn{3}{|c|}{ Percentage of Women Directors } \\
\hline & Model 1 & Model 2 & Model 3 & Model 1 & Model 2 & Model 3 \\
\hline \multirow[t]{2}{*}{ WOB } & $-0.156^{* *}$ & $-0.156^{* *}$ & $-0.143^{*}$ & $-1.335^{\star *}$ & $-1.337^{* *}$ & $-1.226^{* *}$ \\
\hline & $(0.0782)$ & $(0.0783)$ & $(0.0751)$ & $(0.593)$ & $(0.593)$ & $(0.576)$ \\
\hline \multirow[t]{2}{*}{ WOAC } & 0.0808 & 0.0814 & 0.0761 & 0.413 & 0.414 & 0.387 \\
\hline & $(0.133)$ & $(0.132)$ & $(0.130)$ & $(0.430)$ & $(0.430)$ & $(0.428)$ \\
\hline \multirow[t]{2}{*}{ BSIZE } & $0.116^{* * *}$ & $0.116^{* * *}$ & $0.127^{* * *}$ & $0.100^{* * *}$ & $0.100^{* * *}$ & $0.113^{* * *}$ \\
\hline & $(0.0329)$ & $(0.0329)$ & $(0.0298)$ & $(0.0317)$ & $(0.0317)$ & $(0.0286)$ \\
\hline \multirow[t]{2}{*}{ BMEET } & -0.0397 & -0.0400 & -0.0262 & -0.0400 & -0.0403 & -0.0266 \\
\hline & $(0.0306)$ & $(0.0306)$ & $(0.0298)$ & $(0.0306)$ & $(0.0306)$ & $(0.0298)$ \\
\hline \multirow[t]{2}{*}{ ACSIZE } & -0.0509 & -0.0509 & $-0.222^{*}$ & -0.0427 & -0.0426 & $-0.214^{*}$ \\
\hline & $(0.136)$ & $(0.136)$ & $(0.117)$ & $(0.135)$ & $(0.135)$ & $(0.116)$ \\
\hline \multirow[t]{2}{*}{ ACMEET } & $-0.0894^{*}$ & $-0.0888^{*}$ & $-0.101^{* *}$ & $-0.0922^{*}$ & $-0.0915^{\star}$ & $-0.103^{* *}$ \\
\hline & $(0.0473)$ & $(0.0473)$ & $(0.0446)$ & $(0.0472)$ & $(0.0472)$ & $(0.0444)$ \\
\hline \multirow[t]{2}{*}{ SG } & -0.273 & -0.281 & -0.293 & -0.277 & -0.284 & -0.297 \\
\hline & $(0.207)$ & $(0.204)$ & $(0.197)$ & $(0.206)$ & $(0.204)$ & $(0.196)$ \\
\hline \multirow[t]{2}{*}{ LEV } & $-0.0701^{\star \star *}$ & $-0.0701^{* * *}$ & $-0.0635^{\star * *}$ & $-0.0703^{\star * *}$ & $-0.0703^{\star * *}$ & $-0.0636^{* * *}$ \\
\hline & $(0.00422)$ & $(0.00423)$ & $(0.00378)$ & $(0.00424)$ & $(0.00424)$ & $(0.00380)$ \\
\hline \multirow[t]{2}{*}{ ROA } & $0.134^{* * *}$ & $0.135^{\star * *}$ & $0.154^{* * *}$ & $0.135^{\star \star *}$ & $0.135^{\star * *}$ & $0.154^{* * *}$ \\
\hline & $(0.0211)$ & $(0.0210)$ & $(0.0194)$ & $(0.0210)$ & $(0.0209)$ & $(0.0193)$ \\
\hline \multirow[t]{2}{*}{ Big4 } & 0.0855 & 0.0852 & -0.0390 & 0.0857 & 0.0854 & -0.0388 \\
\hline & $(0.107)$ & $(0.107)$ & $(0.0953)$ & $(0.107)$ & $(0.107)$ & $(0.0956)$ \\
\hline \multirow[t]{2}{*}{ Conc5 } & $1.502^{* * *}$ & $1.503^{* * *}$ & $1.422^{* * *}$ & $1.476^{* * *}$ & $1.477^{\star * *}$ & $1.400^{* * *}$ \\
\hline & $(0.292)$ & $(0.292)$ & $(0.283)$ & $(0.293)$ & $(0.293)$ & $(0.284)$ \\
\hline \multirow[t]{2}{*}{ INDUS } & $0.480^{* * *}$ & $0.480^{* * *}$ & - & $0.486^{* * *}$ & $0.486^{* * *}$ & - \\
\hline & $(0.0994)$ & $(0.0995)$ & - & $(0.0991)$ & $(0.0993)$ & - \\
\hline Year dummy & & included & included & & included & included \\
\hline Sector dummy & & & included & & & included \\
\hline \multirow[t]{2}{*}{ Constant } & $2.657^{\star * *}$ & $2.636^{* * *}$ & $2.970^{* * *}$ & $2.781^{* * *}$ & $2.760^{* * *}$ & $3.079^{* * *}$ \\
\hline & $(0.462)$ & $(0.466)$ & $(0.441)$ & $(0.472)$ & $(0.476)$ & $(0.446)$ \\
\hline F-value & 43.13 & 37.52 & 31.50 & 42.98 & 37.41 & 31.40 \\
\hline Sig. & 0.0000 & 0.0000 & 0.0000 & 0.0000 & 0.0000 & 0.0000 \\
\hline R-squared & 0.420 & 0.421 & 0.482 & 0.421 & 0.422 & 0.483 \\
\hline Observ. & 846 & 846 & 846 & 846 & 846 & 846 \\
\hline
\end{tabular}


Mujeeb Saif Mohsen AL-ABSY, Qais ALMAAMARI, Tamer ALKADASH, Ammar HABTOOR /

Table 6: Regression Using the Lag of the Independent Variables

\begin{tabular}{|c|c|c|c|c|c|c|c|c|c|}
\hline \multirow[b]{2}{*}{ Variables } & \multicolumn{3}{|c|}{ At Least One Woman Director } & \multicolumn{3}{|c|}{ Number of Women Directors } & \multicolumn{3}{|c|}{ Percentage of Women Directors } \\
\hline & Model 1 & Model 2 & Model 3 & Model 1 & Model 2 & Model 3 & Model 1 & Model 2 & Model 3 \\
\hline \multirow[t]{2}{*}{$\mathrm{WOB}_{\mathrm{t}-1}$} & $-0.309^{* *}$ & $-0.307^{\star *}$ & -0.232 & $-0.167^{*}$ & $-0.167^{*}$ & $-0.151^{*}$ & $-1.467^{* *}$ & $-1.465^{\star *}$ & $-1.365^{\star *}$ \\
\hline & $(0.143)$ & $(0.143)$ & $(0.144)$ & $(0.0938)$ & $(0.0939)$ & $(0.0901)$ & $(0.706)$ & $(0.706)$ & $(0.688)$ \\
\hline \multirow[t]{2}{*}{ WOAC $_{t-1}$} & 0.216 & 0.215 & 0.130 & 0.204 & 0.204 & 0.155 & 0.874 & 0.876 & 0.732 \\
\hline & $(0.169)$ & $(0.169)$ & $(0.173)$ & $(0.168)$ & $(0.169)$ & $(0.170)$ & $(0.557)$ & $(0.558)$ & $(0.564)$ \\
\hline \multirow[t]{2}{*}{$\mathrm{BSIZE}_{\mathrm{t}-1}$} & $0.0935^{\star \star}$ & $0.0935^{\star *}$ & $0.103^{\star \star \star}$ & $0.0958^{* \star}$ & $0.0958^{* *}$ & $0.106^{* * *}$ & $0.0790^{* *}$ & $0.0791^{* \star}$ & $0.0909^{* *}$ \\
\hline & $(0.0397)$ & $(0.0398)$ & $(0.0363)$ & $(0.0411)$ & $(0.0411)$ & $(0.0376)$ & $(0.0392)$ & $(0.0393)$ & $(0.0359)$ \\
\hline \multirow[t]{2}{*}{ BMEET $_{t-1}$} & -0.0337 & -0.0333 & -0.0160 & -0.0355 & -0.0351 & -0.0167 & -0.0351 & -0.0347 & -0.0167 \\
\hline & $(0.0433)$ & $(0.0434)$ & $(0.0435)$ & $(0.0432)$ & $(0.0433)$ & $(0.0435)$ & $(0.0431)$ & $(0.0431)$ & $(0.0432)$ \\
\hline \multirow[t]{2}{*}{ ACSIZE $_{t-1}$} & 0.0475 & 0.0491 & -0.135 & 0.0428 & 0.0444 & -0.143 & 0.0626 & 0.0642 & -0.127 \\
\hline & $(0.158)$ & $(0.159)$ & $(0.139)$ & $(0.161)$ & $(0.161)$ & $(0.141)$ & $(0.158)$ & $(0.158)$ & $(0.138)$ \\
\hline \multirow[t]{2}{*}{ ACMEET $_{t-1}$} & $-0.140^{* *}$ & $-0.140^{* *}$ & $-0.180^{* * *}$ & $-0.139^{* *}$ & $-0.139^{* *}$ & $-0.178^{\star \star \star}$ & $-0.143^{* *}$ & $-0.143^{* *}$ & $-0.181^{* \star \star}$ \\
\hline & $(0.0657)$ & $(0.0655)$ & $(0.0640)$ & $(0.0654)$ & $(0.0652)$ & $(0.0639)$ & $(0.0652)$ & $(0.0650)$ & $(0.0636)$ \\
\hline \multirow[t]{2}{*}{$S G_{t-1}$} & -0.178 & -0.171 & -0.214 & -0.197 & -0.189 & -0.228 & -0.203 & -0.194 & -0.235 \\
\hline & $(0.232)$ & $(0.232)$ & $(0.230)$ & $(0.234)$ & $(0.234)$ & $(0.231)$ & $(0.234)$ & $(0.234)$ & $(0.231)$ \\
\hline \multirow[t]{2}{*}{ LEV $_{t-1}$} & $-0.0669^{* \star *}$ & $-0.0669^{* * *}$ & $-0.0606^{\star * *}$ & $-0.0664^{* * *}$ & $-0.0664^{* \star \star}$ & $-0.0602^{* * *}$ & $-0.0665^{\star * *}$ & $-0.0665^{\star \star *}$ & $-0.0603^{* * *}$ \\
\hline & $(0.00513)$ & $(0.00513)$ & $(0.00458)$ & $(0.00507)$ & $(0.00507)$ & $(0.00453)$ & $(0.00508)$ & $(0.00508)$ & $(0.00454)$ \\
\hline \multirow{2}{*}{$\mathrm{ROA}_{\mathrm{t}-1}$} & $0.0861^{\star * *}$ & $0.0850^{\star \star \star}$ & $0.0957^{\star * \star}$ & $0.0839^{\star \star *}$ & $0.0827^{\star \star \star}$ & $0.0943^{\star \star \star}$ & $0.0849^{\star \star \star}$ & $0.0838^{\star \star \star}$ & $0.0955^{\star \star \star}$ \\
\hline & $(0.0274)$ & $(0.0273)$ & $(0.0271)$ & $(0.0279)$ & $(0.0278)$ & $(0.0274)$ & $(0.0278)$ & $(0.0277)$ & $(0.0273)$ \\
\hline \multirow[t]{2}{*}{$\mathrm{Big}_{\mathrm{t}-1}$} & -0.00953 & -0.00990 & -0.107 & -0.0206 & -0.0210 & -0.116 & -0.0231 & -0.0235 & -0.119 \\
\hline & $(0.131)$ & $(0.131)$ & $(0.122)$ & $(0.130)$ & $(0.130)$ & $(0.121)$ & $(0.130)$ & $(0.130)$ & $(0.121)$ \\
\hline \multirow[t]{2}{*}{ Conc5 $_{t-1}$} & $1.285^{\star \star *}$ & $1.283^{* * *}$ & $1.261^{* \star *}$ & $1.305^{* \star *}$ & $1.302^{* * *}$ & $1.274^{* * *}$ & $1.282^{* \star *}$ & $1.279^{* \star *}$ & $1.251^{\star \star \star}$ \\
\hline & $(0.367)$ & $(0.368)$ & $(0.363)$ & $(0.365)$ & $(0.366)$ & $(0.359)$ & $(0.366)$ & $(0.366)$ & $(0.360)$ \\
\hline \multirow[t]{2}{*}{ INDUS $_{t-1}$} & $0.533^{\star \star \star}$ & $0.533^{\star \star \star}$ & - & $0.532^{\star \star *}$ & $0.533^{\star * *}$ & - & $0.541^{* \star \star}$ & $0.542^{\star \star *}$ & - \\
\hline & $(0.127)$ & $(0.128)$ & - & $(0.128)$ & $(0.128)$ & - & $(0.128)$ & $(0.128)$ & - \\
\hline $\begin{array}{l}\text { Year } \\
\text { dummy }\end{array}$ & & included & included & & included & included & & included & included \\
\hline $\begin{array}{l}\text { Sector } \\
\text { dummy }\end{array}$ & & & included & & & included & & & included \\
\hline \multirow[t]{2}{*}{ Constant } & $2.990^{\star \star \star}$ & $3.021^{\star \star \star}$ & $3.623^{\star \star \star}$ & $2.949^{\star \star \star}$ & $2.983^{* * *}$ & $3.580^{* * *}$ & $3.041^{* \star \star}$ & $3.075^{\star \star \star}$ & $3.669^{* \star *}$ \\
\hline & $(0.551)$ & $(0.553)$ & $(0.562)$ & $(0.553)$ & $(0.554)$ & $(0.563)$ & $(0.559)$ & $(0.560)$ & $(0.565)$ \\
\hline F-value & 24.04 & 22.19 & 20.63 & 24.16 & 22.29 & 20.66 & 23.98 & 22.12 & 20.57 \\
\hline Sig. & 0.0000 & 0.0000 & 0.0000 & 0.0000 & 0.0000 & 0.0000 & 0.0000 & 0.0000 & 0.0000 \\
\hline R-squared & 0.389 & 0.389 & 0.442 & 0.388 & 0.388 & 0.442 & 0.390 & 0.390 & 0.444 \\
\hline Observ. & 564 & 564 & 564 & 564 & 564 & 564 & 564 & 564 & 564 \\
\hline $\begin{array}{l}{ }^{* * *},{ }^{* * *} \\
\text { Model. } \\
\text { including } \\
\text { of the ma } \\
\text { were des }\end{array}$ & cant at & $10,0$. & $.01, r$ & ely. Tr & $\tan$ & rs ar & Dare & lodel & $\begin{array}{l}\text { main } \\
\text { del by } \\
\text { instead } \\
\text { Variables }\end{array}$ \\
\hline
\end{tabular}


Table 7: Regression Using Different Method of Analysis (Random Effect Panel Data)

\begin{tabular}{|c|c|c|c|}
\hline \multirow{2}{*}{ Variables } & \multicolumn{3}{|c|}{ At Least One Woman Director } \\
\hline & Model 1 & Model 2 & Model 3 \\
\hline \multirow[t]{2}{*}{ WOB } & $-0.265^{\star}$ & $-0.267^{*}$ & -0.241 \\
\hline & $(0.153)$ & $(0.151)$ & $(0.149)$ \\
\hline \multirow[t]{2}{*}{ WOAC } & -0.0333 & -0.0282 & -0.0491 \\
\hline & $(0.198)$ & $(0.197)$ & $(0.191)$ \\
\hline \multirow[t]{2}{*}{ BSIZE } & $0.112^{* * *}$ & $0.112^{\star * *}$ & $0.120^{* * *}$ \\
\hline & $(0.0434)$ & $(0.0433)$ & $(0.0401)$ \\
\hline \multirow[t]{2}{*}{ BMEET } & -0.0383 & -0.0386 & -0.0387 \\
\hline & $(0.0306)$ & $(0.0304)$ & $(0.0306)$ \\
\hline \multirow[t]{2}{*}{ ACSIZE } & -0.104 & -0.102 & -0.156 \\
\hline & $(0.120)$ & $(0.120)$ & $(0.112)$ \\
\hline \multirow[t]{2}{*}{ ACMEET } & -0.0408 & -0.0389 & -0.0428 \\
\hline & $(0.0510)$ & $(0.0503)$ & $(0.0493)$ \\
\hline \multirow[t]{2}{*}{ SG } & -0.223 & $-0.234^{*}$ & $-0.242^{*}$ \\
\hline & $(0.140)$ & $(0.142)$ & $(0.140)$ \\
\hline \multirow[t]{2}{*}{ LEV } & $-0.0666^{* * *}$ & $-0.0665^{* * *}$ & $-0.0630^{* * *}$ \\
\hline & $(0.00579)$ & $(0.00577)$ & $(0.00543)$ \\
\hline \multirow[t]{2}{*}{ ROA } & $0.119^{* * *}$ & $0.120^{* * *}$ & $0.123^{* * *}$ \\
\hline & $(0.0167)$ & $(0.0168)$ & $(0.0166)$ \\
\hline \multirow[t]{2}{*}{ Big4 } & 0.137 & 0.136 & -0.00372 \\
\hline & $(0.174)$ & $(0.174)$ & $(0.153)$ \\
\hline \multirow[t]{2}{*}{ Conc5 } & 0.0584 & 0.0591 & 0.102 \\
\hline & (0.633) & $(0.631)$ & $(0.603)$ \\
\hline \multirow[t]{2}{*}{ INDUS } & $0.493^{* * *}$ & $0.493^{* * *}$ & - \\
\hline & $(0.156)$ & $(0.156)$ & - \\
\hline Year dummy & & included & included \\
\hline Sector dummy & & & included \\
\hline \multirow[t]{2}{*}{ Constant } & $3.403^{* * *}$ & $3.375^{\star \star *}$ & $3.495^{* * *}$ \\
\hline & $(0.750)$ & $(0.744)$ & $(0.761)$ \\
\hline Wald chi2 & 214.13 & 228.90 & 274.33 \\
\hline Sig. & 0.0000 & 0.0000 & 0.0000 \\
\hline R-squared & 0.4087 & 0.4091 & 0.4697 \\
\hline ID & 282 & 282 & 282 \\
\hline Observ. & 846 & 846 & 846 \\
\hline \multicolumn{4}{|c|}{$\begin{array}{l}{ }^{*},{ }^{* *},{ }^{* * *} \text { are significant at level } 0.10,0.05 \text { and } 0.01 \text {, respectively. } \\
\text { The robust standard errors are in the parentheses. Model } 1 \text { is the } \\
\text { main Model. Model } 2 \text { is re-estimated the main model by including } \\
\text { a dummy variable for the years. Model } 3 \text { is re-estimated the main } \\
\text { model by including the company sector (construction, properties, } \\
\text { industrial products, plantation, consumer, technology, trade, and } \\
\text { services), instead of the manufacturing industry (INDUS). Variables } \\
\text { were described in Table } 1 .\end{array}$} \\
\hline
\end{tabular}

\section{Conclusion}

The agency and resource dependence theories have provided an explanation for the role of CG mechanisms, including gender diversity, in monitoring and supporting management in improving firm performance and financial reporting quality. Further, an effective CG can positively enhance the firm's financial stability and ward off financial distress. In particular, the role of women directors in monitoring managers and aligning their behaviors with shareholders' interests has been highlighted by several regulators and policymakers. Several studies have investigated the influence of gender diversity on many variables, including financial performance, earnings quality, and financial reporting quality. However, the role of gender diversity on a firm's financial stability has been neglected by researchers, a gap now filled by the current study.

The results of the study indicate that the women on the board are significantly and negatively associated with a firm's financial stability, that is they are related to a low level of financial stability, which contradicts the agency and resource dependence theories. Regarding women on the AC, the study found no relationship with the firm's financial stability, that is they could not protect the company against financial distress.

The results suggest that policymakers must make firms increase the women representation on the board, as currently, only $53.31 \%$ of the firm-observation indicates at least one woman on the board. Policymakers also need to formulate a policy which requires firms to appoint women to the $\mathrm{AC}$, in addition to the current policy of having women on the board (see, Abdullah \& Ku Ismail, 2016) as currently, only $25.65 \%$ of the firm-observations indicate at least one woman director on the AC. Having women on the board and the AC at the same time could improve efficiency in enhancing the firm's financial stability. That is, the current study proposes that appointing at least one woman to the board and at least one to the $\mathrm{AC}$ could increase their capacity and power in enhancing the firm's performance, financial stability, and reporting quality.

\section{References}

Abdelbadie, R. A., \& Salama, A. (2019). Corporate governance and financial stability in US banks: Do indirect interlocks matter? Journal of Business Research, 104, 85-105. https://doi. org/10.1016/j.jbusres.2019.06.047

Abdul-Rahman, R., \& Ali, F. H. M. (2006). Board, audit committee, culture, and earnings management: Malaysian evidence. Managerial Auditing Journal, 21(7), 783-804. https://doi.org/ $710.1108 / 02686900610680549$.

Abdullah, S. N. (2006). Board structure and ownership in Malaysia: The case of distressed listed companies. Corporate Governance: The International Journal of Business in Society, 6(5), 582-594. https://doi.org/510.1108/14720700610706072. 
Abdullah, S. N. (2014). The causes of gender diversity in Malaysian large firms. Journal of Management \& Governance, 18(4), 1137-1159. https://doi.org/10.1007/s10997-013-9279-0

Abdullah, S. N., \& Ku Ismail, K. N. I. (2012). Do women directors constraint accrual management? Malaysian evidence. Paper presented at the 3rd International Conference on Business and Economics Victoria \& Alfred Waterfront Hotel, Cape Town, South Africa. https://core.ac.uk/download/pdf/300409721.pdf.

Abdullah, S. N., \& Ku Ismail, K. N. I. (2016). Women directors, family ownership, and earnings management in Malaysia. Asian Review of Accounting, 24(4), 525-550. https://doi. org/510.1108/ARA-1107-2015-0067.

Abdullah, S. N., Ku Ismail, K. N. I., \& Nachum, L. (2016). Does having women on boards create value? The impact of societal perceptions and corporate governance in emerging markets. Strategic Management Journal, 37(3), 466-476. https://doi. org/10.1002/smj.2352

Adams, R. B., \& Ferreira, D. (2009). Women in the boardroom and their impact on governance and performance. Journal of Financial Economics, 94(2), 291-309. https://doi.org/10.1016/j. jfineco.2008.10.007

Al-Absy, M., Ismail, K. N. I. K., \& Chandren, S. (2021). The association between real activities and accruals earnings management in Malaysian listed companies. Contaduría y Administración, 66(3), 1-27. http://dx.doi.org/10.22201/ fca. $24488410 \mathrm{e} .2021 .2673$

Al-Absy, M. S. M. (2020). The board chairman's characteristics and financial stability of Malaysian-listed firms. Cogent Business \& Management, 7(1), 1823586.

Al-Absy, M. S. M., Ismail, K. N. I. K., Chandren, S., \& AlDubai, S. A. A. (2020). Involvement of board chairmen in audit committees and earnings management: Evidence from Malaysia. Journal of Asian Finance, Economics, and Business, 7(8), 233-246. https://doi.org/10.13106/jafeb.2020.vol7. no8.233

Al-Absy, M. S. M., Ku Ismail, K. N. I., \& Chandren, S. (2018). Board chairmen's involvement in the nomination and remuneration committees and earnings management. Australasian Accounting, Business and Finance Journal, 12(4), 60-76. http://dx.doi.org/10.14453/aabfj.v14412i14454.14455.

Al-Absy, M. S. M., Ku Ismail, K. N. I., \& Chandran, S. (2019a). Audit Committee chairman characteristics and earnings management: The influence of family chairman. Asia-Pacific Journal of Business Administration, 11(4), 339-370. https://doi. org/310.1108/APJBA-1110-2018-0188.

Al-Absy, M. S. M., Ku Ismail, K. N. I., \& Chandren, S. (2019b). Corporate governance mechanisms and family directives: Aggressive or conservative in earnings management? Academy of Accounting and Financial Studies Journal, 23(1), 1-9. https://www.abacademies.org/journals/month-february-year2019-vol-2023-issue-2011-journal-aafsj-past-issue.html.

Al-Absy, M. S. M., Ku Ismail, K. N. I., \& Chandren, S. (2019c). Corporate governance mechanisms, whistle-blowing policy, and earnings management practices of firms in Malaysia. International Journal of Business, Human and Social Sciences, 13(6), 917-922. https://doi.org/910.5281/zenodo.3299765.

Al-Absy, M. S. M., Ku Ismail, K. N. I., \& Chandren, S. (2019d). Corporate governance mechanisms, whistle-blowing policy, and real earnings management. International Journal of Financial Research, 10(6), 265-282. https://doi.org/210.5430/ ijfr.v5410n5436p5265.

Al-Jaifi, H. A., Al-Rassas, A. H., \& AL-Qadasi, A. A. (2017). Corporate governance strength and stock market liquidity in Malaysia. International Journal of Managerial Finance, 13(5), 592-610. https://doi.org/510.1108/IJMF-1110-2016-0195.

Altman, E. I. (1968). Financial ratios, discriminant analysis, and the prediction of corporate bankruptcy. The Journal of Finance, 23(4), 589-609. https://doi.org/510.1111/j.1540-6261.1968. tb00843.x.

Alves, S. (2012). Ownership structure and earnings management: Evidence from Portugal. Australasian Accounting, Business and Finance Journal, 6(1), 57-74. https://ro.uow.edu.au/aabfj/ vol56/iss $51 / 12$

Anginer, D., Demirguc-Kunt, A., Huizinga, H., \& Ma, K. (2018). Corporate governance of banks and financial stability. Journal of Financial Economics, 130(2), 327-346.

Arun, T. G., Almahrog, Y. E., \& Aribi, Z. A. (2015). Female directors and earnings management: Evidence from UK companies. International Review of Financial Analysis, 39, 137-146.

Bohren, O., \& Staubo, S. (2016). Mandatory gender balance and board independence. European Financial Management, 22(1), 3-30. https://doi.org/10.1111/eufm.12060

Boyd, B. (1990). Corporate linkages and organizational environment: A test of the resource dependence model. Strategic Management Journal, 11(6), 419-430. https://doi. org/410.1002/smj.4250110602.

Buniamin, S., Johari, N. H., Rahman, N. R. A., \& Rauf, F. H. A. (2012). Board diversity and discretionary accruals of the Top 100 Malaysia corporate governance (MCG) index company. African Journal of Business Management, 6(29), 8496-8503. https://doi.org/10.5897/AJBM11.1052

Burke, R. J., \& Vinnicombe, S. (2008). Women on corporate boards of directors: International issues and opportunities. In: S. Vinnicombe, S. Val., R. K. Burke., D. Bilimoria., \& M. House (Eds.), Women on corporate boards of directors: International research and practice (pp. 1-11). Cheltenham, UK: Edward Edgar Publishing Limited

Campbell, K., \& Mínguez-Vera, A. (2008). Gender diversity in the boardroom and firm financial performance. Journal of Business Ethics, 83(3), 435-451. https://doi.org/10.1007/s10551-0079630-y

Carter, D. A., Simkins, B. J., \& Simpson, W. G. (2003). Corporate governance, board diversity, and firm value. Financial Review, 38(1), 33-53. https;//doi.org/10.1111/1540-6288.00034

Chen, Y., Eshleman, J. D., \& Soileau, J. S. (2016). Board gender diversity and internal control weaknesses. Advances in 
Accounting, 33, 11-19. https://doi.org/10.1016/j.adiac.2016. 04.005

Chirilă, V., \& Chirila, C. (2015). Financial market stability: Aquantile regression approach. Procedia Economics and Finance, 20, 125-130. https://doi.org/10.1016/S2212-5671(15)00056-8

Elloumi, F., \& Gueyie, J.-P. (2001). Financial distress and corporate governance: an empirical analysis. Corporate Governance: The International Journal of Business in Society, 1(1), 15-23. https://doi.org/10.1108/14720700110389548.

European Central Bank (2010). Annual Report 2010. Frankfurt, Germany: European Central Bank

Fama, E. F., \& Jensen, M. C. (1983). Separation of ownership and control. The Journal of Law \& Economics, 26(2), 301-325. https://doi.org/10.1086/467037?journalCode=jle

Firtescu, B. (2012). Causes and effects of crises on financial system stability in emerging countries. Procedia Economics and Finance, 3, 489-495.

Gavious, I., Segev, E., \& Yosef, R. (2012). Female directors and earnings management in high-technology firms. Pacific Accounting Review, 24(1), 4-32. https://doi.org/10.1016/ S2212-5671(12)00185-2

Geraldes-Alves, S. M. (2011). The effect of the board structure on earnings management: evidence from Portugal. Journal of Financial Reporting and Accounting, 9(2), 141-160. https:// doi.org/110.1108/19852511111173103.

Gul, F. A., Srinidhi, B., \& Tsui, J. (2007). Do female directors enhance corporate board monitoring? Some evidence from earnings quality. Hong Kong Polytechnic University.

Gull, A. A., Nekhili, M., Nagati, H., \& Chtioui, T. (2018). Beyond gender diversity: How specific attributes of female directors affect earnings management. The British Accounting Review, 50(3), 255-274. https://doi.org/210.1016/j.bar.2017.1009.1001.

Habbash, M. (2011). The role of corporate governance regulations in constraining earnings management practice in Saudi Arabia. In: T. Azid, A. A. Alnodel, \& M. A. Qureshi, M.A. (Eds.), Research in corporate and Shari'ah governance in the Muslim World: Theory and practice (pp. 127-140). Bingley, UK: Emerald Publishing Limited. https://doi.org/10.1108/978-178973-007-420191011

Ku Ismail, K. N. I., \& Abdullah, S. N. (2013). Do women representation on boards and audit committees restrict earnings management? The impact of family ownership in Malaysian firms. Proceedings of the First Aaresoc International Conference on Business and Management, 12-18.

Kyaw, K., Olugbode, M., \& Petracci, B. (2015). Does a genderdiverse board mean fewer earnings management? Finance Research Letters, 14, 135-141. https://doi.org/10.1016/j. frl.2015.05.006

Lakhal, F., Aguir, A., Lakhal, N., \& Malek, A. (2015). Do women on boards and in Top management reduce earnings management? Evidence in France. Journal of Applied Business Research, 31(3), 1107. https://doi.org/10.19030/jabr.v31i3.9236
Larcker, D. F., \& Rusticus, T. O. (2010). On the use of instrumental variables in accounting research. Journal of Accounting and Economics, 49(3), 186-205. https://doi.org/110.1016/j. jacceco.2009.1011.1004.

Lee, T. S., \& Yeh, Y. H. (2004). Corporate governance and financial distress: Evidence from Taiwan. Corporate Governance: An International Review, 12(3), 378-388. https://doi.org/310.1111/ j.1467-8683.2004.00379.x.

Lückerath-Rovers, M. (2009). Female directors on corporate boards provide legitimacy to a company: A resource dependency perspective, Management Online Review, June(2009), 1-13. https://ssrn.com/abstract=1411693.

Lupu, I. (2015). The indirect relation between corporate governance and financial stability. Procedia Economics and Finance, 22, 538-543. https://doi.org/10.1016/S2212-5671(15)00254-3

Mathisen, G. E., Ogaard, T., \& Marnburg, E. (2013). Women in the boardroom: How do female directors of corporate boards perceive boardroom dynamics? Journal of Business Ethics, 116(1), 87-97. https://doi.org/10.1007/s10551-012-1461-9

Miglani, S., Ahmed, K., \& Henry, D. (2015). Voluntary corporate governance structure and financial distress: Evidence from Australia. Journal of Contemporary Accounting \& Economics, 11(1), 18-30. https://doi.org/10.1016/j.jcae.2014.1012.1005.

Mohammad, W. M. W., Wasiuzzaman, S., \& Salleh, N. M. Z. N. (2016). Board and audit committee effectiveness, ethnic diversification, and earnings management: a study of the Malaysian manufacturing sector. Corporate Governance: the International Journal of Business in Society, 16(4), 726-746. https://doi.org/710.1108/CG-1106-2015-0085.

Moradi, M., Salehi, M., Bighi, S. J. H., \& Najari, M. (2012). A study of the relationship between board characteristics and earning management: Iranian scenario. Universal Journal of Management and Social Sciences, 2(3), 12-29.

Ow-Yong, K., \& Kooi-Guan, C. (2000). Corporate governance codes: A comparison between Malaysia and the UK. Corporate Governance: An International Review, 8(2), 125-132. https:// doi.org/110.1111/1467-8683.00190.

Prencipe, A., \& Bar-Yosef, S. (2011). Corporate governance and earnings management in family-controlled companies. Journal of Accounting, Auditing \& Finance, 26(2), 199-227. https://doi. org/110.1177/0148558X11401212.

Roychowdhury, S. (2006). Earnings management through real activities manipulation. Journal of Accounting and Economics, 42(3), 335-370. https://doi.org/310.1016/j. jacceco.2006.1001.1002.

Rubio, M., \& Yao, F. (2020). Bank capital, financial stability, and Basel regulation in a low interest-rate environment. International Review of Economics \& Finance, 67, 378-392. https://doi.org/10.1016/j.iref.2020.02.008

Sakawa, H., \& Watanabel, N. (2018). Family control and ownership monitoring in Stakeholder-oriented corporate governance. Management Decision. https://doi.org/10.1108/MD-04-20180480 
Salleh, N. M. Z. N., \& Haat, M. H. C. (2013). Audit committee diversity-Malaysian evidence after the revision of MCCG. Malaysian Accounting Review, 12(2), 91-113. http://dx.doi. org/110.24191/mar.v24112i24192.24192.

Salleh, Z., Hashim, H. A., \& Mohamad, N. R. (2012). Accrual quality: The presence of women directors on audit committee boards. Corporate Ownership \& Control, 10(1), 675-680. https://doi.org/610.22495/cocv22410i22491c22497art22493.

Shahwan, T. M. (2015). The effects of corporate governance on financial performance and financial distress: Evidence from Egypt. Corporate Governance, 15(5), 641-662. https://doi. org/610.1108/CG-1111-2014-0140.

Singh, V., Terjesen, S., \& Vinnicombe, S. (2008). Newly appointed directors in the boardroom:: How do women and men differ? European Management Journal, 26(1), 48-58. https://doi. org/10.1016/j.emj.2007.10.002

Srinidhi, B., Gul, F. A., \& Tsui, J. (2011). Female directors and earnings quality. Contemporary Accounting Research, 28(5), 1610-1644. https://doi.org/10.1111/j.1911-3846.2011. 01071.x

Staubo, S. (2010). Do female directors increase board independence? Paper presented at the Norwegian School of Management, Oslo, Norway.

Sun, J., Liu, G., \& Lan, G. (2011). Does female directorship on independent audit committees constrain earnings management? Journal of Business Ethics, 99(3), 369-382. https://doi. org/10.1007/s10551-010-0657-0

Thiruvadi, S., \& Huang, H. W. (2011). Audit committee gender differences and earnings management. Gender in Management: An International Journal, 26(7), 483-498. https://doi. org $/ 10.1108 / 17542411111175469 /$ full $/ \mathrm{html}$
Ugrin, J. C., Mason, T. W., \& Emley, A. (2017). Culture's consequence: The relationship between income-increasing earnings management and IAS/IFRS adoption across cultures. Advances in Accounting, 37, 140-151. https://doi. $\operatorname{org} / 110.1016 / j$.adiac.2017.1004.1004.

Upadhyay, A., \& Zeng, H. (2014). Gender and ethnic diversity on boards and corporate information environment. Journal of Business Research, 67(11), 2456-2463. https://doi. org/10.1016/j.jbusres.2014.03.005

Wan-Hussin, W. N., \& Bamahros, H. M. (2013). Do investment in and the sourcing arrangement of the internal audit function affect audit delay? Journal of Contemporary Accounting \& Economics, 9(1), 19-32. https://doi.org/10.1016/j. jcae.2012.1008.1001.

Wang, Y., \& Clift, B. (2009). Is there a "business case" for board diversity? Pacific Accounting Review, 21(2), 88-103. https:// doi.or/10.1108/01140580911002044

Yuliana, R., Anshori, M., \& Alim, M. N. (2015). Real earnings management in the Indonesian sharia capital market. ProcediaSocial and Behavioral Sciences, 211, 866-873. https://doi. org/810.1016/j.sbspro.2015.1011.1114.

Yusoff, W., Fauziah, W., \& Ramin, A. K. (2013). Women on corporate boards: Malaysian perspectives. Paper presented at the 2nd International Conference on Technology Management, Business, and Entrepreneurship, Mahkota Hotel Melaka Malaysia. http://eprints.uthm.edu.my/id/eprint/5181

Zalata, A. M., Tauringana, V., \& Tingbani, I. (2018). Audit committee financial expertise, gender, and earnings management: Does the gender of the financial expert matter? International Review of Financial Analysis, 55, 170-183. https://doi.org/10.1016/j. jbusres.2019.06.047 